\title{
Insulin-dependent glucose metabolism in dairy cows with variable fat mobilization around calving
}

\author{
C. Weber, ${ }^{*}$ C. T. Schäff, ${ }^{*}$ U. Kautzsch, ${ }^{*}$ S. Börner, ${ }^{*}$ S. Erdmann, ${ }^{*}$ S. Görs, ${ }^{*}$ M. Röntgen,† H. Sauerwein,† \\ R. M. Bruckmaier,§ C. C. Metges, ${ }^{*}$ B. Kuhla, ${ }^{*}$ and H. M. Hammon*1 \\ *Institute of Nutritional Physiology ("Oskar Kellner"), and \\ †Institute of Muscle Biology and Growth, Leibniz Institute for Farm Animal Biology (FBN), 18196 Dummerstorf, Germany \\ łInstitute of Animal Science, Physiology and Hygiene Unit, University of Bonn, 53113 Bonn, Germany \\ $\S$ Veterinary Physiology, Vetsuisse Faculty, University of Bern, 3001 Bern, Switzerland
}

\begin{abstract}
Dairy cows undergo significant metabolic and endocrine changes during the transition from pregnancy to lactation, and impaired insulin action influences nutrient partitioning toward the fetus and the mammary gland. Because impaired insulin action during transition is thought to be related to elevated body condition and body fat mobilization, we hypothesized that overconditioned cows with excessive body fat mobilization around calving may have impaired insulin metabolism compared with cows with low fat mobilization. Nineteen dairy cows were grouped according to their average concentration of total liver fat (LFC) after calving in low [LLFC; LFC $<24 \%$ total fat/dry matter (DM); $\mathrm{n}=9$ ] and high (HLFC; LFC $>24.4 \%$ total fat/DM; $\mathrm{n}$ $=10$ ) fat-mobilizing cows. Blood samples were taken from wk 7 antepartum (ap) to wk 5 postpartum (pp) to determine plasma concentrations of glucose, insulin, glucagon, and adiponectin. We applied euglycemichyperinsulinemic (EGHIC) and hyperglycemic clamps (HGC) in wk 5 ap and wk 3 pp to measure insulin responsiveness in peripheral tissue and pancreatic insulin secretion during the transition period. Before and during the pp EGHIC, $\left[{ }^{13} \mathrm{C}_{6}\right]$ glucose was infused to determine the rate of glucose appearance (GlucRa) and glucose oxidation (GOx). Body condition, back fat thickness, and energy-corrected milk were greater, but energy balance was lower in HLFC than in LLFC. Plasma concentrations of glucose, insulin, glucagon, and adiponectin decreased at calving, and this was followed by an immediate increase of glucagon and adiponectin after calving. Insulin concentrations ap were higher in HLFC than in LLFC cows, but the EGHIC indicated no differences in peripheral insulin responsiveness among cows ap and pp. However, GlucRa and GOx:GlucRa
\end{abstract}

Received February 11, 2016.

Accepted March 31, 2016.

${ }^{1}$ Corresponding author: hammon@fbn-dummerstorf.de during the pp EGHIC were greater in HLFC than in LLFC cows. During HGC, pancreatic insulin secretion was lower, but the glucose infusion rate was higher pp than ap in both groups. Plasma concentrations of nonesterified fatty acids decreased during HGC and EGHIC, but in both clamps, pp nonesterified fatty acid concentrations did not reach the ap levels. The study demonstrated a minor influence of different degrees of body fat mobilization on insulin metabolism in cows during the transition period. The distinct decrease in the glucose-dependent release of insulin pp is the most striking finding that explains the impaired insulin action after calving, but does not explain differences in body fat mobilization between HLFC and LLFC cows. Key words: glucose metabolism, insulin secretion, insulin responsiveness, endogenous glucose production

\section{INTRODUCTION}

The transition period is characterized by dramatic metabolic changes that are targeted at meeting the energy requirements of dairy cows while channeling substrates to the fetus and the mammary glands (Bell, 1995; Bauman, 2000). Because of insufficient feed intake and the resulting negative energy balance during the transition period, cows mobilize body tissue to match their energy demands (Grummer, 1993; Ingvartsen and Andersen, 2000; Drackley et al., 2001). With the onset of lactation, the extreme increase in glucose requirements for milk production results in elevated endogenous glucose production and reduced glucose utilization in peripheral tissues, which provides adequate amounts of glucose for milk synthesis (Bauman, 2000; Drackley et al., 2001; Aschenbach et al., 2010). Enormous variation exists in the degree of fat mobilization around the time of calving, as high-yielding dairy cows follow different metabolic strategies to cover their energy demands during milk production (Kessel et al., 2008; Hammon et al., 2009; Weber et al., 2013). Previously, Tamminga et al. (1997) observed marked 
differences in fat mobilization among cows during the first $8 \mathrm{wk}$ of lactation, ranging from 8 to $57 \mathrm{~kg}$ of body fat. Hence, liver fat concentration (LFC) shows large inter-individual variations among cows as a function of the increasing plasma concentration of nonesterified fatty acids (NEFA) resulting from lipolysis in fat depots and the storage of fat as triglycerides in the liver (Grummer, 1993; Drackley et al., 2001; Hammon et al., 2009).

Insulin plays a key role in regulating energy metabolism during the transition period in dairy cows (Bauman, 2000; Vernon, 2005; De Koster and Opsomer, 2013), and its antilipolytic effect inhibits the release of NEFA during this time (Brockman and Laarveld, 1986; Andersen et al., 2002; Hayirli, 2006). In fact, the transition period is characterized by an insulinresistant state; namely, reduced insulin sensitivity and responsiveness in distinct peripheral tissues (Bell, 1995; Vernon, 2005; De Koster and Opsomer, 2013), and after calving, there is a decrease in the concentration of plasma insulin (Reist et al., 2003; Hammon et al., 2009; Weber et al., 2013). This reduced insulin status in dairy cows is part of the homeorhetic metabolic regulation that guides nutrients, notably glucose, to tissues that are less dependent on insulin action (e.g., the placenta and the lactating mammary gland; Bell, 1995; Bauman, 2000; Ingvartsen and Andersen, 2000). However, changes in insulin action are tissue-specific and vary among organs and metabolic pathways in ruminants (Faulkner and Pollock, 1990; Vernon, 2005; De Koster and Opsomer, 2013).

In addition, a high body fat content and elevated fat mobilization or administration affect insulin sensitivity and responsiveness (Boden et al., 2002; Pires et al., 2007; De Koster et al., 2015) as well as the secretion of pancreatic insulin (Bossaert et al., 2008; Gupta et al., 2012; Salin et al., 2012). Therefore, dairy cows that exhibit elevated fat mobilization and increased LFC around calving may be exposed to impaired insulin action during the transition period. Pancreatic insulin secretion and insulin responsiveness in peripheral tissues can best be investigated using hyperglycemic (HGC) and euglycemic-hyperinsulinemic clamps (EGHIC), respectively (DeFronzo et al., 1979; De Koster and Opsomer, 2013). The objective of the present study was to elucidate the effect of variable body fat mobilization around the time of calving on insulin-dependent glucose metabolism, including pancreatic insulin secretion and tissue responsiveness to insulin, in dairy cows during late pregnancy and early lactation. In addition, the insulin-dependent glucose rate of appearance in plasma (GlucRa) and glucose oxidation (GOx) were investigated postpartum (pp). We hypothesized that insulin action around the time of calving is impaired in dairy cows with a greater body fat mobilization and that the extent of impairment differs between late gestation and early lactation.

\section{MATERIALS AND METHODS}

\section{Animals, Husbandry, and Feeding}

All treatments were conducted in accordance with the guidelines for the use of animals as experimental subjects of the State Government of MecklenburgWestern Pomerania (Registration No. LALLF M-V/ TSD/7221.3-2.1-021/09). For the present study, 20 multiparous German Holstein cows from a local farm were chosen on the basis of their milk yield during one previous lactation (>10,000 kg/305 d) and age (second to fourth lactation). To reduce genetic variation in fat metabolism, all cows were selected for heterozygosity at a polymorphic locus in the acyl-CoA-diacylglycerol acyltransferase 1 gene (DGAT1 K232A: Lys or Ala at position 232), which affects fat metabolism in muscle and the mammary gland (Thaller et al., 2003).

The present study on insulin-dependent glucose metabolism focused on insulin responsiveness in peripheral tissues and pancreatic insulin secretion, using EGHIC and HGC at wk 5 antepartum (ap) and wk 3 pp. The study was part of a comprehensive project regarding energy metabolism and the regulation of feed intake in dairy cows during the transition period (Schäff et al., 2012; Börner et al., 2013). The cows were investigated from wk 7 ap until wk 5 pp; animal management and performance data have been published previously (Schäff et al., 2012; Börner et al., 2013). Cows were kept in tiestalls and fed twice daily for ad libitum allowance with a TMR adapted for the dry period (the far-off diet from wk 7 to wk 4 ap and the close-up diet from wk 3 ap until calving) or lactation. The ingredients and chemical compositions of the different diets were determined according to the recommendations of the German Society of Nutritional Physiology (GfE, 2001, 2008; Table 1).

Cows were grouped according to their mean total LFC on d 3, 18, and 30 after calving in low [LLFC; $\mathrm{LFC}<24 \%$ (mean $\pm \mathrm{SE}: 20.0 \pm 2.0 \%$ ) total fat/DM liver tissue; $\mathrm{n}=9$ ] and high [HLFC; LFC $>24.4 \%$ (mean \pm SE: $30.2 \pm 1.8 \%$ ) total fat/DM liver tissue; $n$ $=10]$ fat-mobilizing cows. Due to severe sickness during the trial, 1 LLFC cow was excluded from sampling. Changes in LFC during the entire experimental period have been reported by Schäff et al. (2012).

Feed intake in wk 5 ap and wk 3 pp was recorded daily, and BW was measured to calculate DMI per kilogram of BW as well as energy balance (EB). Energy balance (expressed in $\mathrm{MJ} / \mathrm{cow} \times \mathrm{d}$ ) was calculated for 
the dry period as $\mathrm{EB}=\mathrm{NE}_{\mathrm{L}}$ intake $-(0.293 \times \mathrm{kg}$ of $\left.\mathrm{BW}^{0.75}+0.044 \times \mathrm{e}^{0.0165 \times \text { days since conception }}\right)(\mathrm{GfE}, 2001$, 2008). After parturition, cows were milked twice daily (0330 and $1500 \mathrm{~h}$ ); milk samples were collected at wk $3 \mathrm{pp}$ and analyzed for milk fat, milk protein, and milk lactose by an infrared spectrophotometry (MilkoScan; Foss GmbH, Rellingen, Germany) to calculate ECM as follows: $\mathrm{ECM}=[(0.038 \times \mathrm{g}$ of fat $+0.024 \times \mathrm{g}$ of protein $+0.017 \times \mathrm{g}$ of lactose $) \times \mathrm{kg}$ of milk $] \div 3.14$ (Reist et al., 2003). For the lactation period, EB was calculated as $\mathrm{EB}=\mathrm{NE}_{\mathrm{L}}$ intake $-\left(0.293 \times \mathrm{BW}^{0.75}+\right.$ $3.14 \times \mathrm{ECM})$ (Hammon et al., 2009). Back fat thickness (BFT) was measured at wk 5 ap and wk 3 pp via ultrasound (SonoSite 180 Plus; SonoSite Inc., Bothell, WA) according to the method of Schröder and Staufen- biel (2006); at the same time, BCS was assigned based on a 1- to 5-point scale (Edmonson et al., 1989).

\section{Feed Sampling and Analyses}

Dry matter content was determined weekly from the TMR and grass and corn silages. To determine DM, feed samples were dried at $60^{\circ} \mathrm{C}$ for $24 \mathrm{~h}$ and then at $105^{\circ} \mathrm{C}$ for $3 \mathrm{~h}$. Samples from the TMR were collected monthly, and those from grass and corn silage were collected every $2 \mathrm{wk}$ and stored at $-20^{\circ} \mathrm{C}$. Nutrient composition was determined at the Institute for Farm Animal Science and Technology (University of Rostock, Germany) and the Agricultural Analysis and Research Institute (LUFA, Rostock, Germany). Dry matter, CP,

Table 1. Ingredients and chemical composition ( $\mathrm{g} / \mathrm{kg}$ of DM unless otherwise noted) of the far-off dry period, close-up dry period, and early lactation diets ${ }^{1}$

\begin{tabular}{|c|c|c|c|}
\hline \multirow[b]{2}{*}{ Component } & \multicolumn{3}{|c|}{ Diet } \\
\hline & Far-off dry period & Close-up dry period & Early lactation \\
\hline \multicolumn{4}{|l|}{ Ingredient } \\
\hline Grass silage & 749 & 302 & 202 \\
\hline Corn silage & 29 & 399 & 350 \\
\hline Barley straw & 114 & 54 & 16 \\
\hline Hay & 95 & 39 & 26 \\
\hline Concentrate $^{2,3}$ & $1.4^{2}$ & $124^{2}$ & $296^{3}$ \\
\hline Molassed sugar beet pulp ${ }^{4}$ & 4.1 & 5.5 & 62 \\
\hline Extracted rapeseed meal & & 45 & 32 \\
\hline Mineral feed ${ }^{5,6}$ & $7.7^{5}$ & $1.8^{5}$ & $6.7^{5}$ \\
\hline Anionic salts ${ }^{7}$ & & 12 & \\
\hline Cattle salt $^{8}$ & & 1.0 & 0.7 \\
\hline Propylene glycol $^{9}$ & & 16 & 8.8 \\
\hline \multicolumn{4}{|l|}{ Chemical analysis } \\
\hline Utilizable protein $^{10}$ & 128 & 137 & 163 \\
\hline Crude fat & 38 & 33 & 30 \\
\hline $\mathrm{NE}_{\mathrm{L}}, \mathrm{MJ} / \mathrm{kg}$ of $\mathrm{DM}$ & 5.9 & 6.5 & 7.1 \\
\hline NDF & 335 & 317 & 298 \\
\hline $\mathrm{ADF}$ & 189 & 137 & 140 \\
\hline
\end{tabular}

${ }^{1}$ Far-off dry period was from 7 to 4 wk before calving, and close-up dry period was from wk 3 before calving until parturition.

${ }^{2}$ Concentrate MF 2000 (Vollkraft Mischfutterwerke GmbH, Güstrow, Germany): 33\% extracted soy meal, 20\% corn, $17 \%$ wheat gluten, $13 \%$ wheat, $8 \%$ extracted rapeseed meal, $5 \%$ sugar beet pulp, $2 \%$ sodium hydrogen carbonate, $1.3 \%$ calcium carbonate, $0.2 \%$ sodium chloride, $8.0 \mathrm{MJ}$ of $\mathrm{NE}_{\mathrm{L}} / \mathrm{kg}$ of DM, $204 \mathrm{~g}$ of utilizable protein $/ \mathrm{kg}$ of DM.

${ }^{3}$ Concentrate Universal 18/3 (Vollkraft Mischfutterwerke GmbH): 20-40\% cereals (triticale, rye, wheat, barley); $25 \%$ rapeseed expeller; lower contents of malt-germs, wheat gluten, wheat bran, peeled oat bran, beet pulp chips, molasses and glycerin, minerals, vitamins; $6.7 \mathrm{MJ}$ of $\mathrm{NE}_{\mathrm{L}} / \mathrm{kg}$ of $\mathrm{DM} ; 160 \mathrm{~g}$ of utilizable protein/ $\mathrm{kg}$ of DM.

${ }^{4}$ Trockenschnitzel (Arp, Thordsen, Rautenberg GmbH \& Co KG, Sollerupmühle, Germany): 7.3 MJ of NE $/ \mathrm{kg}$ of DM, $153 \mathrm{~g}$ of utilizable protein $/ \mathrm{kg}$ of DM.

${ }^{5}$ Rinderstolz 9235 far-off and close-up dry period (Salvana Tiernahrung GmbH, Sparrieshoop, Germany): $75 \%$ crude ash, $4.5 \%$ calcium, $6 \%$ phosphorus, $10 \%$ sodium, $12 \%$ magnesium, vitamins.

${ }^{6}$ Rinderstolz 9522 lactation (Salvana Tiernahrung GmbH): $92 \%$ crude ash, 20\% calcium, 5\% phosphorus, 6\% magnesium, $8 \%$ sodium, vitamins.

${ }^{7}$ Anionen-Mix 1141 (Salvana Tiernahrung GmbH): 14\% calcium, 12.5\% sulfur, 12\% chlorine, 10\% magnesium, $2 \%$ phosphorus, vitamins.

${ }^{8}$ Esco SOLSEL Mineralleckstein mit Kupfer (European Salt Company GmbH \& Co. KG, Hannover, Germany): $37 \%$ sodium, $1.6 \%$ calcium, $0.6 \%$ magnesium.

${ }^{9}$ Propylenglykol USP (Dr. Pieper Technologie und Produktentwicklung GmbH, Wuthenow, Germany).

${ }^{10} \mathrm{GfE}$ (2001). 
ADF, NDF, starch, and sugar were determined according to Naumann and Bassler (2004).

\section{Blood and Liver Tissue Sampling and Analyses}

From wk 7 ap to wk 5 pp, weekly blood samples for the measurement of plasma glucose, insulin, glucagon, and adiponectin were collected from the jugular vein in EDTA-containing tubes (Vacuette; Greiner BioOne $\mathrm{GmbH}$, Kremsmünster, Austria). During the last week before and after parturition, 2 blood samples were obtained per week. Samples were immediately placed on ice and centrifuged within $30 \mathrm{~min}$ (at $1,565 \times g$ for 20 min at $4^{\circ} \mathrm{C}$ ), and the harvested plasma was stored at $-20^{\circ} \mathrm{C}$ until analysis. Plasma glucose concentrations were analyzed by spectrophotometry (ABX Pentra 400; Axon Laboratory, Reichenbach, Germany) at the Clinic for Cattle (University of Veterinary Medicine at Hannover Foundation, Hannover, Germany) using a kit (no. 553-230) from MTI Diagnostics (Idstein, Germany). Insulin and glucagon were measured by RIA as recently described (Hammon et al., 2009; Weber et al., 2013), and the plasma concentrations of adiponectin were measured by the Institute of Animal Science, Physiology and Hygiene Unit, Bonn University (Bonn, Germany), and determined by an indirect, competitive ELISA according to the method described by Mielenz et al. (2013).

Liver samples were obtained by needle biopsy under local anesthesia on d 3, 18, and 30 after calving (Schäff et al., 2012), and the tissue samples were immediately frozen in liquid nitrogen and stored at $-80^{\circ} \mathrm{C}$ until analysis. In preparation for the analysis, liver tissue was homogenized under liquid nitrogen, and the carbon and nitrogen contents were analyzed by combustion and by elemental analysis using mass spectrometry (EA 1108, Carlo Erba Instruments, Rodano, Italy; Delta S, Finnigan MAT, San Jose, CA). The concentration of total liver fat was calculated according to the following equation: liver fat $(\%$ of $\mathrm{DM})=1.3038 \times \mathrm{C}(\%$ of $\mathrm{DM})-4.237 \times \mathrm{N}(\%$ of $\mathrm{DM})-0.58 \times$ glycogen $(\%$ of DM $)-0.5215 \times$ glucose $(\%$ of DM) (Duske et al., 2009). Liver glycogen was determined using a commercial photometric test kit based on the amyloglucosidase-catalyzed release of glucose (no. 10207748035; Boehringer Mannheim, Mannheim, Germany; Duske et al., 2009). Data on liver glycogen in these cows were published recently (Schäff et al., 2012).

\section{Clamp Studies}

One day before the clamp studies in wk 5 ap and wk 3 pp, catheters (Certofix mono, B. Braun Melsungen
AG, Melsungen, Germany) were implanted into both jugular veins of the cows. The HGC was initiated after a 7-h feed withdrawal, and the basal plasma concentrations of glucose, NEFA, and insulin were determined in 3 basal blood plasma samples drawn 30, 20, and 10 min before the start of the glucose infusion. The aim of the HGC study was to increase plasma glucose concentrations by $50 \% \pm 5 \%$ above the basal level. At $0830 \mathrm{~h}$, infusion of a $40 \%$ (wt/vol) glucose solution (B. Braun Melsungen AG) began at a rate of $4 \mathrm{~mL} / \mathrm{min}$ and lasted for $4 \mathrm{~h}$. During the HGC, blood plasma was sampled every 5 min and immediately analyzed for glucose concentrations (1500 Sport YSI Lactate analyzer, Kreienbaum, Langenfeld, Germany) and, if necessary, the glucose infusion rate (GIR) was adjusted to maintain hyperglycemia. After the start of infusion, further blood samples were taken every $10 \mathrm{~min}$ in K-EDTA monovettes (Sarstedt AG und Co. KG, Nürnbrecht, Germany) and centrifuged at $1,565 \times g$ for 20 min at $4^{\circ} \mathrm{C}$. The harvested plasma was stored at $-20^{\circ} \mathrm{C}$ to determine insulin (every $10 \mathrm{~min}$ ) and NEFA concentrations (every $20 \mathrm{~min}$ ). Plasma insulin concentrations were measured as described above, and plasma NEFA concentrations were analyzed by spectrophotometry (ABX Pentra 400; Axon Laboratory) at the Clinic for Cattle (University of Veterinary Medicine Hannover, Foundation, Germany) using a kit (no. 434-91795) from Wako Chemicals GmbH (Neuss, Germany).

The EGHIC study was conducted $2 \mathrm{~d}$ after the HGC study. After $7 \mathrm{~h}$ of feed withdrawal and after basal blood sampling as described for the HGC, the EGHIC study was initiated at $1000 \mathrm{~h}(t=0 \mathrm{~min})$. The infusion with bovine insulin (Hybri-Max, Sigma-Aldrich Chemie GmbH, Steinheim, Germany; activity $31 \mathrm{U} /$ $\mathrm{mg}$ ) was at a constant rate of $6 \mathrm{mU} / \mathrm{kg}$ of $\mathrm{BW}$ per minute over the next $6 \mathrm{~h}$ (Blum et al., 1999; Gohlke et al., 2013). The insulin infusion solution for the EGHIC was prepared individually for each cow by dissolving purified bovine insulin in $460 \mathrm{~mL}$ of a sterile solution consisting of $0.9 \% \mathrm{NaCl}, 0.1 \% \mathrm{BSA}, 2.4 \% \mathrm{KCl}$, and $4 \%$ blood plasma of the same cow in double-distilled water. Glucose infusion commenced 5 min after insulin infusion and started at a rate of $4 \mathrm{~mL} / \mathrm{min}$ using a $40 \%$ (wt/vol) glucose solution (B. Braun Melsungen AG). During the EGHIC study, plasma was sampled every 5 min, and the glucose concentration was immediately analyzed as for the HGC. The glucose infusion rate was adjusted every 5 min to maintain the established basal plasma glucose concentration. The blood samples for the insulin and NEFA measurements were handled as described for the HGC.

The clamp studies were evaluated as follows. Basal glucose and insulin concentrations in plasma (bGC 
and $\mathbf{b I C}$ ) were calculated as the arithmetic means of the glucose and insulin concentrations of the 3 basal samples taken before starting the infusions. The steadystate (ss) glucose and insulin concentrations (ssGC and ssIC) in plasma were calculated as the arithmetic means of the plasma concentrations during the last 1.5 $\mathrm{h}$ (HGC) or $2 \mathrm{~h}$ (EGHIC) of the clamp studies. The steady-state glucose infusion rate (ssGIR) was computed as the arithmetic mean of the GIR during the same period used for the calculation of ssGC and ssIC. The metabolic clearance rate of insulin (MCR) was determined as the ratio between the insulin infusion rate and the increase in ssIC above bIC in the EGHIC (De Fronzo et al., 1979). The insulin sensitivity index (ISI) was calculated as the ratio of ssGIR $(\mu \mathrm{mol} / \mathrm{kg}$ of BW per min) to ssIC ( $\mu \mathrm{g} / \mathrm{L})$, according to Mitrakou et al. (1992), and expressed as the amount of glucose utilized per unit of insulin. The revised quantitative insulin sensitivity check index (rQUICKI; Holtenius and Holtenius, 2007) values were determined using the following equation: $\mathrm{rQUICKI}=1 /[\log \mathrm{bGC}(\mathrm{mg} / \mathrm{dL})+$ $\log \mathrm{bIC}(\mu \mathrm{U} / \mathrm{mL})+\log$ bNEFA $(\mathrm{mmol} / \mathrm{L})]$, where bGC, $\mathrm{bIC}$, and bNEFA represent the basal concentrations of glucose, insulin, and NEFA in plasma, respectively. Furthermore, for the analysis of the HGC studies, the absolute and relative increases in plasma insulin levels $\left(\mathbf{I I}_{\text {abs }}\right.$ and $\left.\mathbf{I I}_{\text {rel }}\right)$ were calculated as $\mathrm{II}_{\text {abs }}=\mathrm{ssIC}-\mathrm{bIC}$ and $\mathrm{II}_{\mathrm{rel}}=\mathrm{ssIC} / \mathrm{bIC}$.

\section{Tracer Studies}

Before and during the pp EGHIC studies, the glucose rate of appearance in plasma (GlucRa) was determined using a primed, continuous intravenous $\left[{ }^{13} \mathrm{C}_{6}\right]$ glucose (99 atom \%, Euriso-Top GmbH, Saarbrücken, Germany) infusion. The tracer glucose infusion started at $0700 \mathrm{~h}$ (time $t=-180 \mathrm{~min}$ relative to start of the EGHIC study) with a bolus injection of $5.38 \mu \mathrm{mol}$ of $\left[{ }^{13} \mathrm{C}_{6}\right]$ glucose/ $\mathrm{kg}$ of BW followed immediately by a constant infusion $\left(7.53 \mu \mathrm{mol}\right.$ of $\left[{ }^{13} \mathrm{C}_{6}\right]$ glucose $/ \mathrm{kg}$ of $\mathrm{BW}$ per $\mathrm{h}$ ) for $9 \mathrm{~h}$ (from -180 to $360 \mathrm{~min}$ ). Blood was collected at $-190,-185,-90,-60,-30,0,60,120$, $180,210,240,270,300,330$, and $360 \mathrm{~min}$ relative to the start of the EGHIC study in lithium-heparinized monovettes, to measure $\left[{ }^{13} \mathrm{C}_{6}\right]$ glucose enrichment for the assessment of GlucRa, and in full-blood K-EDTA tubes (Sarstedt), to determine ${ }^{13} \mathrm{CO}_{2}$ enrichment for the calculation of glucose oxidation rate.

Plasma $\left[{ }^{13} \mathrm{C}_{6}\right]$ glucose enrichment was determined by converting glucose to its aldonitrile pentaacetate derivative as previously described (Junghans et al., 2010). It was analyzed by GC-MS (QP 2010, GC 2010, Shimadzu Deutschland GmbH, Duisburg, Germany) using positive chemical ionization and $\mathrm{m} / z 334$ and 328 as the diagnostic ion fragments to calculate $\mathrm{m}+6 / \mathrm{m}+0$ (Junghans et al., 2010).

To determine the concentration of ${ }^{13} \mathrm{C}$ in blood $\mathrm{CO}_{2}$, $1 \mathrm{~mL}$ of lactic acid ( $10 \% \mathrm{wt} / \mathrm{wt}$ ) was added to $1 \mathrm{~mL}$ of whole blood in 10-mL screw-cap glass tubes (Exetainer, Labco Ltd., Lampeter, UK) that had previously been flushed with argon. Samples were incubated for at least $2 \mathrm{~h}$ at room temperature, and the ${ }^{13} \mathrm{C}:{ }^{12} \mathrm{C}$ isotopic ratio of the released blood $\mathrm{CO}_{2}$ was measured in the headspace using gas isotope ratio mass spectrometry (Delta Plus XL, Thermo Fisher Scientific GmbH, Dreieich, Germany) coupled with a Gas Bench II (Thermo Fisher Scientific GmbH). Enrichments are expressed as ${ }^{13} \mathrm{C}$ atom percent excess.

The GlucRa derived from intravenous $\left[{ }^{13} \mathrm{C}_{6}\right]$ glucose infusion was calculated as GlucRa $=\mathrm{I}_{\mathrm{IV}} \times\left[\left(\mathrm{IE}_{\text {inf }} / \mathrm{IE}_{\mathrm{IV}}\right)\right.$ - 1], where $\mathrm{I}_{\mathrm{IV}}$ is the intravenous infusion rate of $\left[{ }^{13} \mathrm{C}_{6}\right]$ glucose $[\mu \mathrm{mol} / \mathrm{kg}$ of $\mathrm{BW}$ per hour $]$; $\mathrm{IE}_{\text {inf }}$ is the isotopic enrichment (mol \% excess) of $\left[{ }^{13} \mathrm{C}_{6}\right]$ glucose in the tracer infusion solution; and $\mathrm{IE}_{\mathrm{IV}}$ is the isotopic enrichment (mol ratio excess) of $\left[{ }^{13} \mathrm{C}_{6}\right]$ glucose in plasma over the isotopic steady-state baseline (absence of a significant slope). The GlucRa was calculated under basal conditions before the start of the EGHIC study (from -90 to $0 \mathrm{~min}$ ) to determine the basal endogenous glucose production rate (beGP) and under the EGHIC conditions (from 180 min to $360 \mathrm{~min}$, GlucR $\mathbf{a}_{\mathbf{E G H I C}}$ ). In addition, GlucRa $\mathrm{EGHIC}_{\mathrm{E}}$ was corrected for the infusion of unlabeled glucose during the EGHIC, which resulted in the calculation of endogenous glucose production during EGHIC (ceGP) as follows: ceGP $=$ GlucRa $\mathrm{EGHIC}-\mathrm{GI}_{\mathrm{CLAMP}}$, where $\mathrm{GI}_{\text {CLAMP }}$ is exogenous glucose infusion $(\mathrm{mmol} / \mathrm{kg}$ of BW per hour).

Glucose oxidation rate $(\mathbf{G O x}$; mmol/ $\mathrm{kg}$ of $\mathrm{BW}$ per hour) was calculated before (bGOx) and during the clamp $(\mathbf{c G O x})$ study as follows: $\mathrm{GOx}=\mathrm{CO}_{2} \mathrm{Ra} \times \mathrm{IE}_{\mathrm{CO} 2}$ $\times\left(6 \times \mathrm{IE}_{\mathrm{IV}}\right)^{-1}$ (Kien, 1989). The $\mathrm{IE}_{\mathrm{CO} 2}$ (atom \% excess) is the steady-state ${ }^{13} \mathrm{C}$ enrichment of $\mathrm{CO}_{2}$ derived from oxidized glucose in the blood before $(-60$ to 0 min relative to the start of the clamp) and during the EGHIC (210 to $360 \mathrm{~min}$ after the start of the clamp), and IE $\mathrm{IV}$ (mol \% excess) is the steady-state isotopic enrichment of $\left[{ }^{13} \mathrm{C}_{6}\right]$ glucose in plasma. The $\mathrm{CO}_{2}$ rate of appearance $\left(\mathbf{C O}_{2} \mathbf{R a} ; \mathrm{mmol} / \mathrm{kg}\right.$ of $\mathrm{BW}$ per hour $)$ was calculated based on the metabolic $\mathrm{CO}_{2}$ production $\left(\mathrm{V}_{\mathrm{CO} 2}\right.$ in $\mathrm{L} /$ $\mathrm{kg}$ of $\mathrm{BW}$ per day) of lactating Holstein cows, which was measured by indirect calorimetry (Börner et al., 2013) and calculated as follows: $\mathrm{CO}_{2} \mathrm{Ra}=\mathrm{VCO}_{2} \times$ $\left(22.4 \times \mathrm{RF}\left[{ }^{13} \mathrm{C}\right]\right)^{-1}$, where 22.4 is the amount $(\mathrm{L})$ in 1 mol of $\mathrm{CO}_{2}$ with the appropriate corrections to convert to $\mathrm{mmol} / \mathrm{kg}$ of BW per hour. The recovery factor (RF) 0.7 was used to correct for the incomplete recovery of 
${ }^{13} \mathrm{C}$ in breath from the rate of $\mathrm{CO}_{2}$ appearance in the blood (Junghans et al., 2007).

\section{Statistics}

Clamp data as well as performance data and the plasma concentrations of glucose, insulin, glucagon, and adiponectin during the entire experimental period were evaluated by repeated-measures ANOVA using PROC MIXED in SAS for Windows (release 9.4; SAS Institute, 2013). The ANOVA model contained the fixed effects of group, time, and the group $\times$ time interaction, and the covariates included block, milk yield in the second lactation, DIM in the second lactation, and length of the dry period. Covariates were excluded from the model when not significant. Repeated measures on each cow were taken into account by using the repeated statement of the MIXED procedure with an autoregressive residual covariance structure. Plasma glucose, insulin, glucagon, and adiponectin data were analyzed separately for each observation period as follows: the levels of the time repeated variable were wk 7 to wk 1 before calving for the ap period, wk 3 before calving until wk 3 after calving for the transition period, wk 1 to wk 5 after calving for the pp period, and wk 7 ap to wk $5 \mathrm{pp}$ for the entire observation period. Data from the tracer study were evaluated with the GLM procedure in SAS for Windows (release 9.4; SAS Institute, 2013) with group as a fixed effect and BW as a covariate.

The least squares means and their standard errors were computed for each fixed effect in the ANOVA model, and the differences in the least squares means between group and time were tested using the TukeyKramer procedure. Differences with $P<0.05$ were considered significant and $P<0.1$ as a trend.

\section{RESULTS}

Mean total hepatic fat concentration differed between groups $(P<0.01)$ with $195 \pm 0.1 \mathrm{mg} / \mathrm{g}$ of DM liver tissue for LLFC cows and $306 \pm 0.2 \mathrm{mg} / \mathrm{g}$ of DM for HLFC cows. Performance and fat mobilization data ap and pp were published by Schäff et al. (2012).

\section{Body Condition, Feed Intake, Energy Balance, and Milk Yield and Composition}

Body weight, BCS, and BFT decreased $(P<0.05$; Table 2) from late pregnancy to early lactation in both groups and were higher $(P<0.05)$ in HLFC than in LLFC cows ap as well as pp. Dry matter intake was higher $(P<0.05$; Table 2$)$ in wk 3 pp than in wk 5 ap, but it was similar among groups at both time points. However, DMI relative to kilograms of $\mathrm{BW}$ tended to be higher $(P<0.1)$ in LLFC than in HLFC cows in wk 5 ap and in wk 3 pp. Energy balance was positive ap but negative in the pp period $(P<0.05)$ and was slightly lower $(P<0.1)$ in HLFC than in LLFC cows during early lactation. Milk yield did not differ between groups in wk $3 \mathrm{pp}$, but there was a trend $(P<0.1$; Table 2) toward higher ECM in HLFC than in LLFC cows. Milk fat concentration tended to be higher $(P=$ 0.1 ; Table 2) in HLFC than LLFC cows, whereas milk protein and lactose concentrations were similar among groups.

\section{Blood Glucose and Hormones During the Observation Period}

Plasma glucose concentrations remained constant during the ap period but decreased rapidly $(P<0.01$;

Table 2. Animal performance data in wk 5 antepartum and wk 3 postpartum of cows with low and high liver fat concentrations (LLFC and HLFC, respectively)

\begin{tabular}{|c|c|c|c|c|c|c|c|c|}
\hline \multirow[b]{2}{*}{ Variable $^{1}$} & \multicolumn{2}{|c|}{ Antepartum } & \multicolumn{2}{|c|}{ Postpartum } & \multirow[b]{2}{*}{$\mathrm{SE}$} & \multicolumn{3}{|c|}{ ANOVA ( $P$-value) } \\
\hline & LLFC & HLFC & LLFC & HLFC & & Group & Time & Group $\times$ Time \\
\hline $\mathrm{BW}, \mathrm{kg}$ & 685 & 761 & 622 & 673 & 18.1 & 0.02 & $<0.001$ & 0.3 \\
\hline $\mathrm{BCS}$ & 2.89 & 3.62 & 2.38 & 2.93 & 0.2 & 0.02 & 0.004 & 0.6 \\
\hline Back fat thickness, mm & 16.3 & 21.6 & 14.2 & 19.9 & 1.4 & 0.01 & 0.03 & 0.8 \\
\hline DMI, kg & 11.0 & 11.0 & 16.4 & 17.0 & 0.7 & 0.7 & $<0.001$ & 0.5 \\
\hline DMI/kg of BW, kg & 1.63 & 1.44 & 2.82 & 2.58 & 0.1 & 0.08 & $<0.001$ & 0.8 \\
\hline Energy balance, MJ/d & 28.7 & 24.0 & -52.6 & -63.8 & 4.7 & 0.08 & $<0.001$ & 0.5 \\
\hline Milk yield, $\mathrm{kg}$ & & & 39.7 & 40.3 & 1.6 & 0.8 & & \\
\hline ECM, kg & & & 43.0 & 46.0 & 1.1 & 0.08 & & \\
\hline Milk fat, $\%$ & & & 4.75 & 5.51 & 0.3 & 0.1 & & \\
\hline Milk protein, \% & & & 3.04 & 3.15 & 0.2 & 0.6 & & \\
\hline Milk lactose, $\%$ & & & 4.78 & 4.68 & 0.1 & 0.4 & & \\
\hline
\end{tabular}

${ }^{1}$ Values are LSM with SE. 
Figure 1A) after calving in both groups in a similar fashion. Plasma insulin concentrations were higher $(P$ $<0.05)$ in HLFC than in LLFC cows during the dry period and decreased $(P<0.05)$ in both groups around calving, whereas the decrease (interaction group $\times$ time: $P<0.05)$ was greater in HLFC than in LLFC cows. After calving, insulin concentrations increased in both groups, but plasma insulin was higher at the end of the study in HLFC than in LLFC cows $(P<0.05$; Figure 1B). Plasma glucagon concentrations decreased from dry-off until calving and increased after parturition $(P<0.01$; Figure $1 \mathrm{C})$ in both groups. Plasma adiponectin concentrations were fairly constant during the dry period, decreased rapidly $(P<0.05$; Figure
1D) from wk 2 before calving until nadir, and increased pp to the precalving plasma level in both HLFC and LLFC cows.

\section{Glucose, Insulin, and NEFA Responses During the Hyperglycemic Clamp}

Plasma glucose increased during the glucose infusion and then remained constant during the steady state period at a level $50 \%$ above the basal plasma glucose concentration. Basal and steady-state plasma glucose concentrations did not differ between groups before or after calving, but basal plasma glucose concentrations were lower $(P<0.01$; Figure 2 ; Table 3$)$ pp than ap.
A
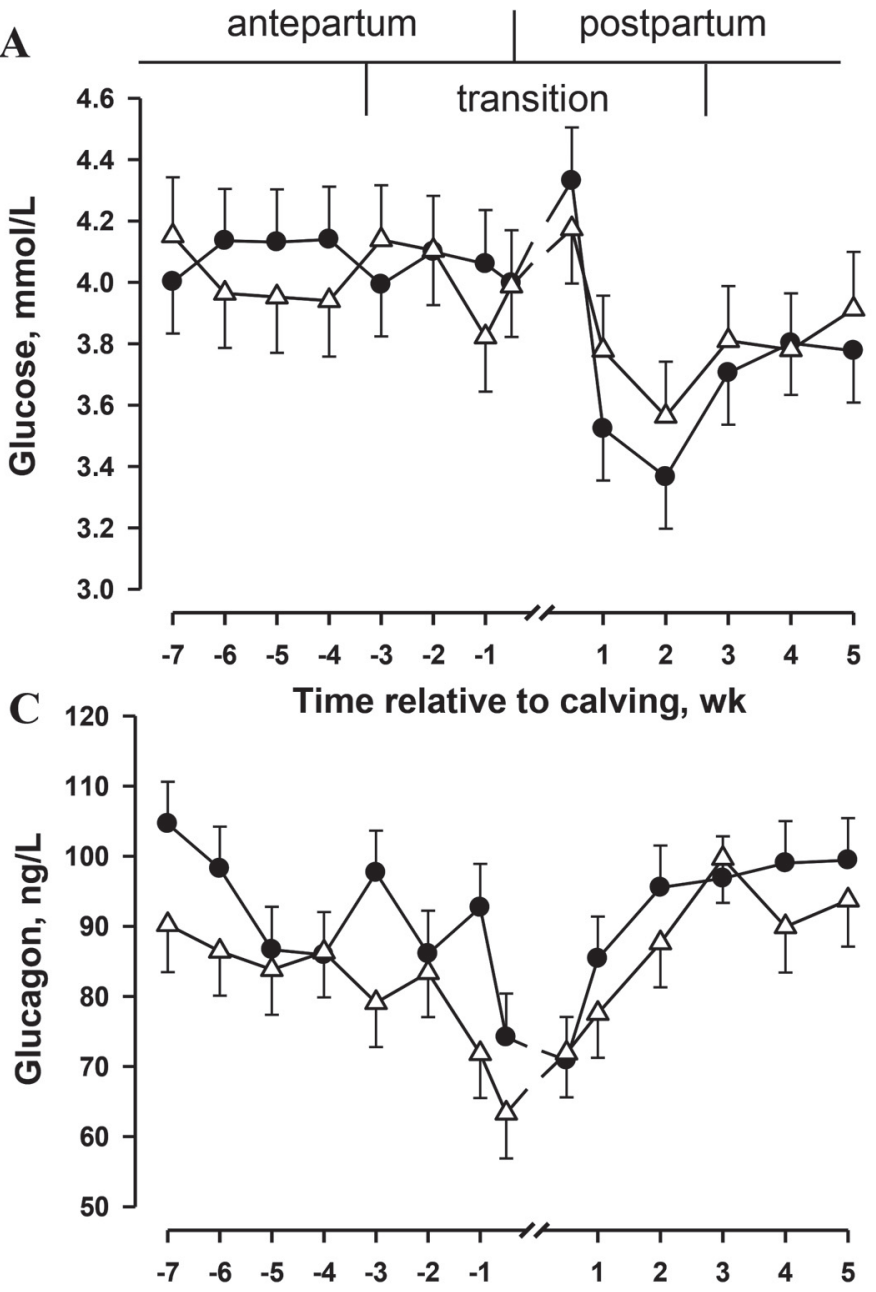

Time relative to calving, wk
B

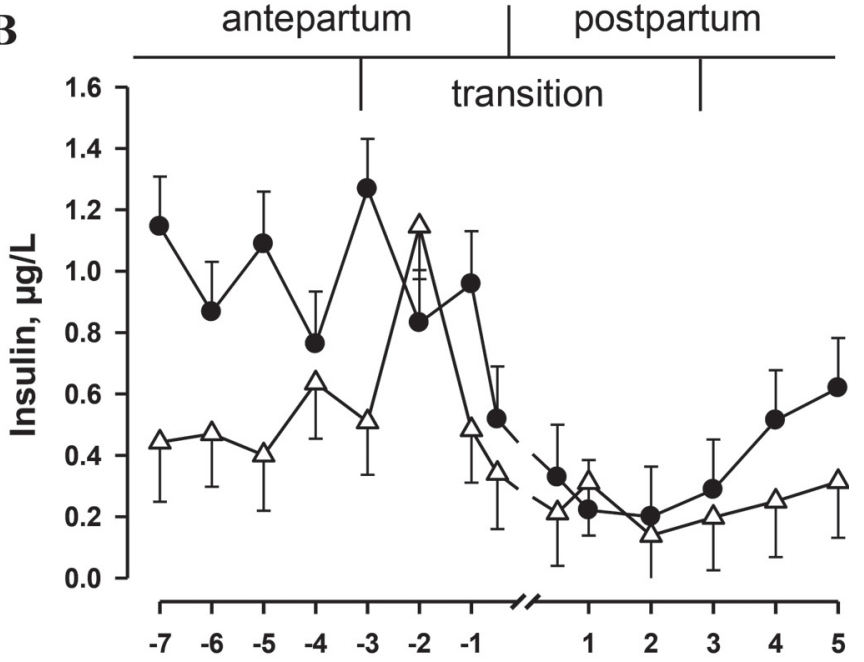

D

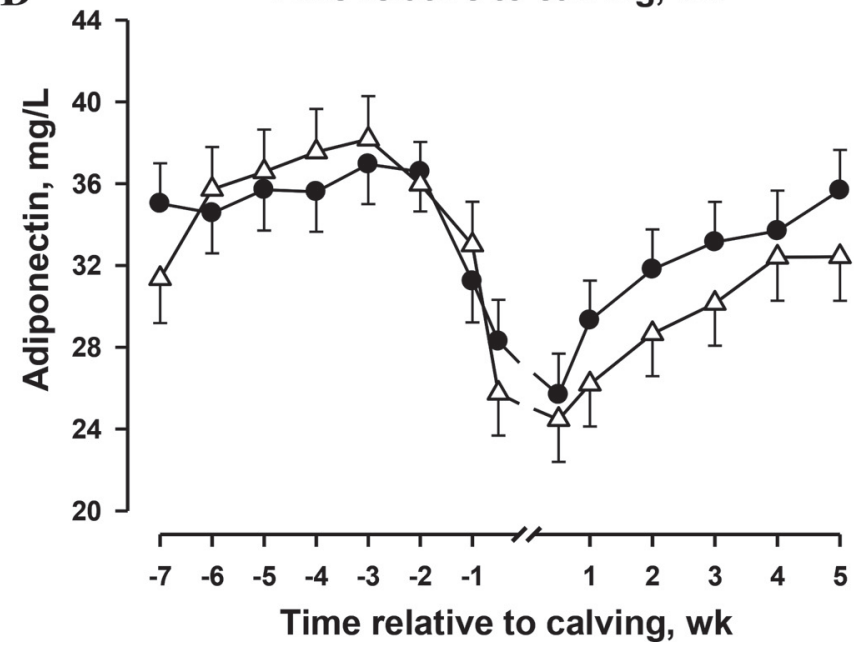

Figure 1. Plasma glucose, insulin, glucagon, and adiponectin concentrations from wk 7 antepartum (ap) to wk 5 postpartum (pp) in cows with low $(\Delta ; \mathrm{n}=9)$ and high $(\mathbf{0} ; \mathrm{n}=10)$ liver fat concentrations. Values are LSM \pm SE. Effects $(P<0.05)$ for glucose: time during transition, pp, and entire study. Effects $(P<0.05)$ for insulin: group during ap and entire study; time during transition, pp, and entire study; group $\times$ time during transition and entire study. Effects $(P<0.05)$ for glucagon: time during ap, transition, pp, and entire study; group $\times$ time during ap, transition, and entire study. Effects $(P<0.05)$ for adiponectin: time during ap, transition, pp, and entire study. 
The block factor affected $(P<0.05)$ plasma glucose concentrations in HGC. The ssGIR did not differ between groups before or after calving, but ssGIR was higher $(P<0.05)$ pp than ap.

After the start of glucose infusion, plasma insulin concentrations increased $(P<0.001)$ much more ap than $\mathrm{pp}$, and thus plasma ssIC was higher ap than pp $(P<0.001$; Figure 2; Table 3). Basal insulin concentrations ap were slightly higher $(P=0.1)$ in HLFC than in LLFC cows, and the $\mathrm{II}_{\text {abs }}$ decreased $(P<0.001)$ in HGC from ap to pp in both groups. The $\mathrm{II}_{\text {rel }}$ decreased in LLFC cows from ap to pp HGC, but in HLFC cows, the $\mathrm{II}_{\mathrm{rel}}$ did not change with time (interaction group $x$ time: $P<0.05$; Table 3). Plasma NEFA concentrations were similar among groups in the ap and pp HGC, but basal plasma NEFA concentrations were higher $(P<$ 0.001) pp than ap (Figure 2; Table 3). During glucose infusion, the NEFA concentrations rapidly decreased $(P<0.001)$ ap and pp, but ssNEFA pp did not reach the level of ssNEFA measured in the ap HGC.

\section{Glucose, Insulin, and NEFA Responses and Glucose Turnover and Oxidation}

In the EGHIC, basal plasma glucose concentrations were higher $(P<0.05)$ ap than pp, and glucose concentrations remained constant during the steady-state period. For ssGIR, there was an indication of a group $\times$ time interaction $(P=0.1$; Figure 3 ; Table 4$)$ with an increase of ssGIR in HLFC cows, but a decrease in
A

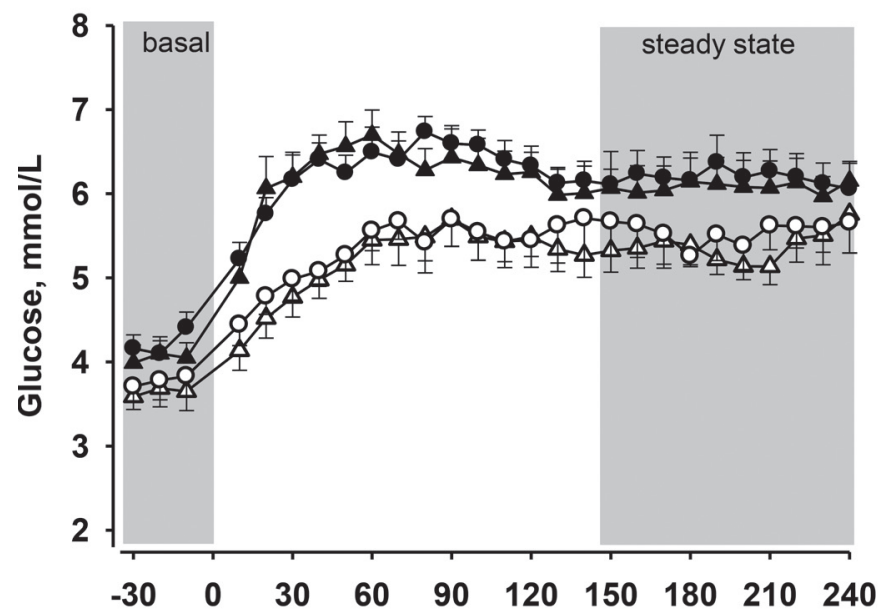

C

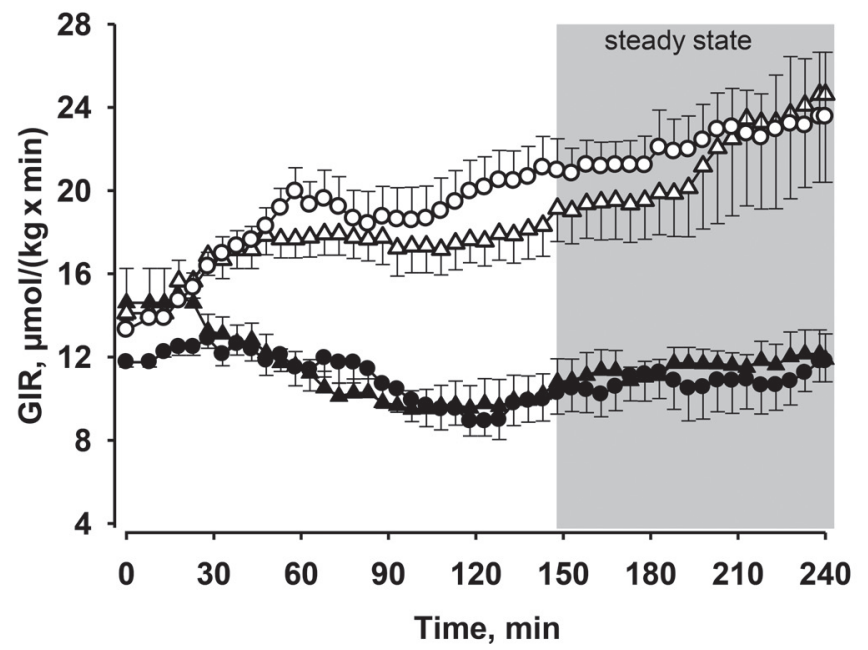

B

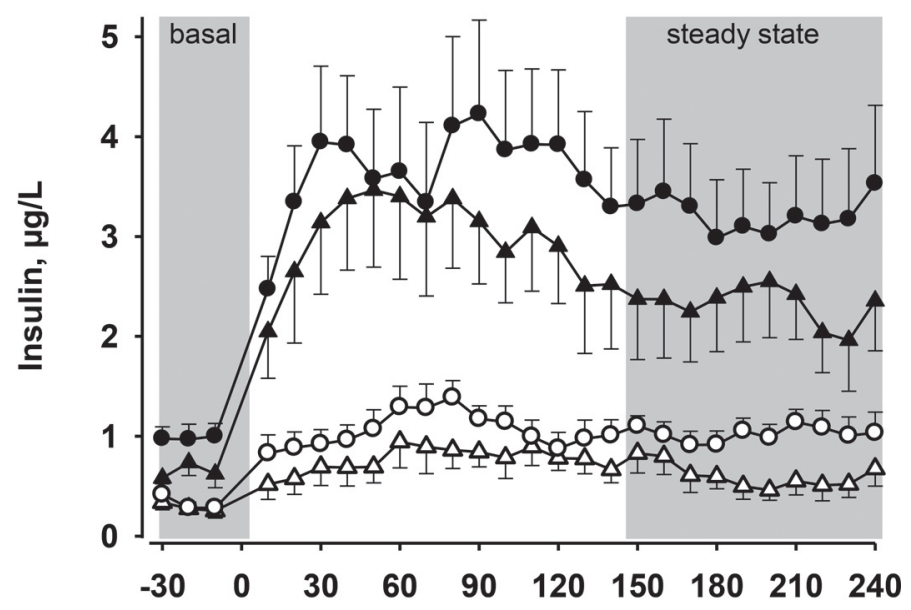

D

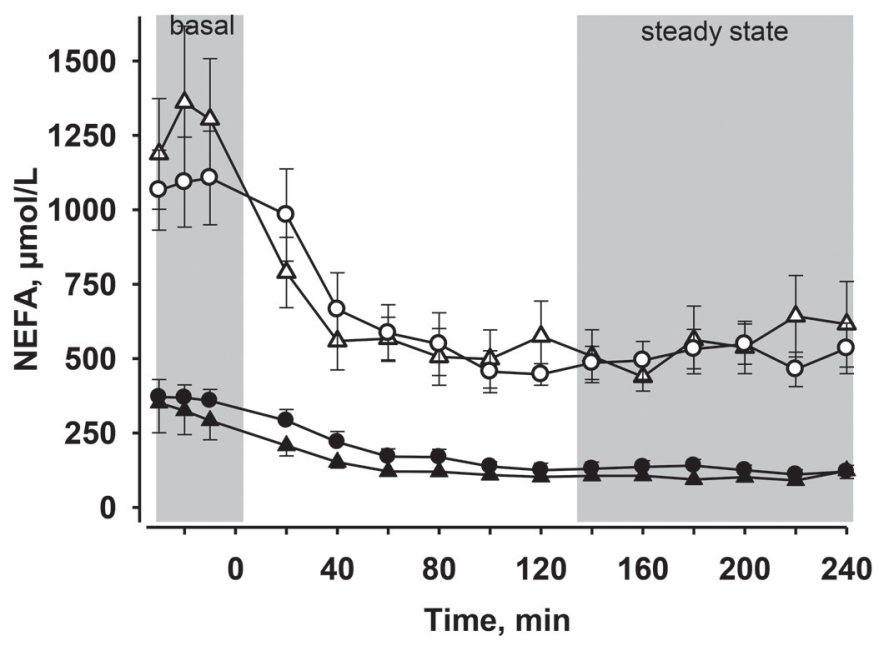

Figure 2. Plasma glucose, plasma insulin, glucose infusion rate (GIR), and plasma nonesterified fatty acids (NEFA) before (basal) and during a hyperglycemic clamp (HGC) with a steady state for the last $90 \mathrm{~min}$ in cows with low $[\mathrm{n}=9$; antepartum (ap) $\mathbf{\Delta}$, postpartum (pp) $\boldsymbol{\Delta}]$ and high $(\mathrm{n}=10$; ap $\bullet$, pp $\bigcirc)$ liver fat concentrations. Values are LSM $\pm \mathrm{SE}$. 
Table 3. Plasma concentrations of glucose, insulin, and nonesterified fatty acids (NEFA) before and during the steady state, glucose infusion rate, and absolute and relative insulin increase during hyperglycemic clamp antepartum and postpartum in cows with low and high liver fat concentrations (LLFC and HLFC, respectively)

\begin{tabular}{|c|c|c|c|c|c|c|c|c|}
\hline Variable $^{1,2}$ & \multicolumn{2}{|c|}{ Antepartum } & \multicolumn{2}{|c|}{ Postpartum } & $\mathrm{SE}$ & \multicolumn{3}{|c|}{ ANOVA ( $P$-value $)$} \\
\hline $\mathrm{bGC}, \mathrm{mmol} / \mathrm{L}$ & 4.10 & 3.99 & 3.83 & 3.63 & 0.15 & 0.3 & 0.07 & 0.8 \\
\hline bIC, $\mu \mathrm{g} / \mathrm{L}$ & 0.65 & 0.98 & 0.29 & 0.32 & 0.11 & 0.1 & 0.001 & 0.1 \\
\hline $\mathrm{ssIC}, \mu \mathrm{g} / \mathrm{L}$ & 2.31 & 3.22 & 0.61 & 0.99 & 0.43 & 0.2 & 0.001 & 0.5 \\
\hline $\mathrm{II}_{\mathrm{abs}}, \mu \mathrm{g} / \mathrm{L}$ & 1.66 & 2.24 & 0.32 & 0.66 & 0.36 & 0.3 & $<0.001$ & 0.7 \\
\hline $\mathrm{ssNEFA}, \mu \mathrm{mol} / \mathrm{L}$ & 104 & 127 & 551 & 515 & 56.0 & 0.9 & 0.001 & 0.6 \\
\hline
\end{tabular}

${ }^{1}$ Values are LSM with SE.

${ }^{2} \mathrm{bGC}=$ basal plasma glucose concentration; ssGIR = steady-state glucose infusion rate; bIC = basal plasma insulin concentration; ssIC = steady-state mean plasma insulin concentrations; $\mathrm{II}_{\mathrm{abs}}=$ absolute increase in plasma insulin concentration; $\mathrm{II}_{\mathrm{rel}}=$ relative increase in plasma insulin concentration; bNEFA = basal plasma NEFA concentration; ssNEFA = steady-state mean plasma NEFA concentration.

LLFC cows from ap to the pp period. Basal plasma insulin concentrations were higher $(P<0.05)$ ap than pp and tended to be lower $(P<0.1$; Figure 3; Table $4)$ in LLFC than in HLFC cows before calving. The metabolic clearance rate increased $(P<0.05$; Table 4$)$ from the ap to the pp period but did not differ between groups. The ISI was not affected by time or group in the EGHIC. A group $\times$ time interaction was indicated in rQUICKI $(P=0.1$; Table 4$)$ with a slight decrease from ap to pp in LLFC cows but an increase in HLFC cows. Basal plasma NEFA concentrations were higher in both groups $(P<0.001)$ pp than ap and decreased rapidly during EGHIC to reach the steady state level $(P<0.05$; Figure 3 ; Table 4$)$, but plasma NEFA concentrations pp did not reach ap concentrations and did not differ between groups.

During the pp EGHIC, beGP and ceGP were not significantly different between groups, but GlucRa $\mathrm{E}_{\mathrm{EHHIC}}$ was higher $(P<0.05$; Table 5$)$ in HLFC than in LLFC cows. Body weight had a significant effect on GlucRa $_{\text {EGHIC }}(P<0.05)$, and endogenous glucose production decreased with insulin infusion to $18 \%$ of the pre-clamp level but without group-related differences. Glucose oxidation, basal and during the clamp, did not differ among groups. The bGOx relative to beGP was similar among groups, but there was a trend $(P=0.1$; Table 5) toward a higher cGOx to GlucRa $\mathrm{EGHIC}_{\mathrm{C}}$ ratio in LLFC than in HLFC cows.

\section{DISCUSSION}

The dairy cows investigated in this study were grouped according to LFC pp. Cows differed in their body condition and fat mobilization around the time of calving, as indicated by a greater release of NEFA in HLFC than in LLFC cows (Schäff et al., 2012). In addition, milk fat content was greater in HLFC than in LLFC cows immediately after calving, whereas milk yield was comparable between cows. Dairy cows with high BCS and fat mobilization are known to have greater milk fat content immediately after calving (Ohgi et al., 2005; Hammon et al., 2009). Plasma glucose concentrations decreased markedly in the pp period, but the decrease was not affected by the different degrees of fat mobilization, a result contrasting previous findings (Hammon et al., 2009; Weber et al., 2013). Instead, HLFC cows had greater insulin concentrations and lower glucagon:insulin ratios in blood plasma (data not shown), which also contrasts previous findings (Hammon et al., 2009; Weber et al., 2013). Reasons for these differences among studies are not obvious at present but different insulin concentrations before calving may indicate the range of variation among cows during late gestation.

Euglycemic-hyperinsulinemic clamps before calving did not indicate differences in insulin responsiveness in peripheral tissues in HLFC and LLFC cows, which could have been assumed from elevated basal plasma insulin concentrations ap in HLFC cows occurring as compensation for an impaired peripheral insulin action (De Koster and Opsomer, 2013). The ssGIR, RQUICKI, and ISI did not differ between HLFC and LLFC cows before calving. This is in contrast to the findings of De Koster et al. (2015), who showed a negative association between ssGIR and body condition (BCS, back fat thickness, adipose depots in carcass) during EGHIC in dry cows. However, De Koster et al. (2015) used increasing insulin doses over time of infusion and established insulin-dose response curves during the EGHIC to calculate insulin sensitivity. We used only one relatively high insulin dose to assess insulin responsiveness by ssGIR, so the use of several increasing insulin doses 
during the EGHIC infusion, as done by De Koster et al. (2015), might have revealed different insulin sensitivity between HLFC and LLFC cows in the dry period. However, insulin sensitivity was not investigated in the present study. Findings in sheep, where induced obesity led to decreased insulin sensitivity but not to impaired maximal insulin responsiveness, may support this suggestion (Bergman et al., 1989). Even the high dose of insulin used in EGHIC did not completely inhibit endogenous glucose production after calving, as indicated by the pp ceGP measurement in these cows, a phenomenon previously described in veal and neonatal calves (Hugi et al., 1998; Scheuer et al., 2006). Neither beGP nor ceGP differed between groups, but the level of endogenous glucose production was consistent with
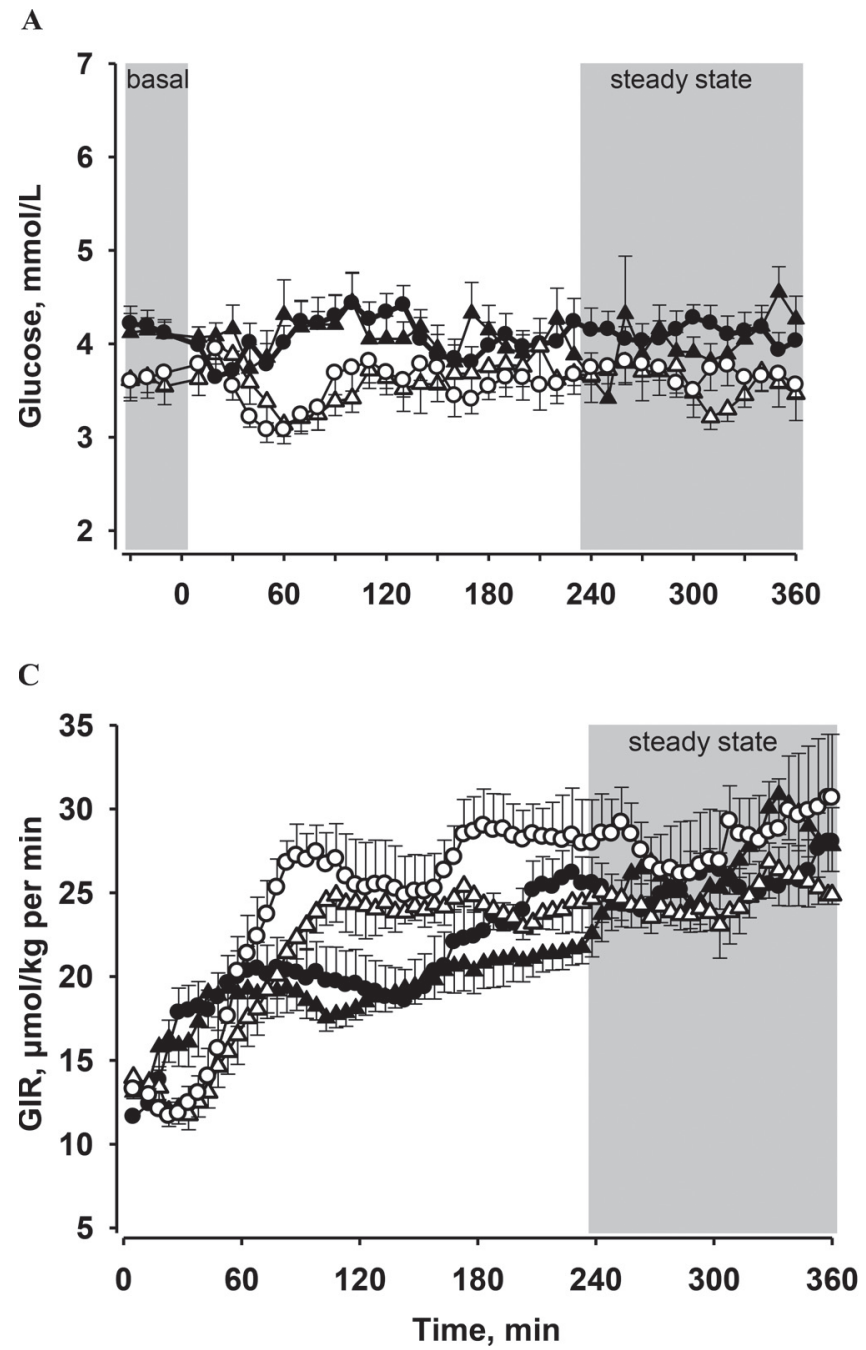

recently presented data from our group (Hammon et al., 2008; Gohlke et al., 2013; Hötger et al., 2013).

As evident in the precalving measurements, the EGHIC studies after calving did not indicate changes in peripheral insulin responsiveness in cows that differed in body condition and degree of fat mobilization around calving. Furthermore, plasma adiponectin concentration did not differ among cows, and recent findings have indicated no changes in AMP-activated protein kinase (AMPK), a key factor in detecting hepatic energy metabolism by adiponectin and insulin, in the liver between groups (Hayirli, 2006; Schäff et al., 2012; Combs and Marliss, 2014). Adiponectin is known to increase insulin sensitivity, and its plasma concentration decreases around calving in dairy cows (Mielenz

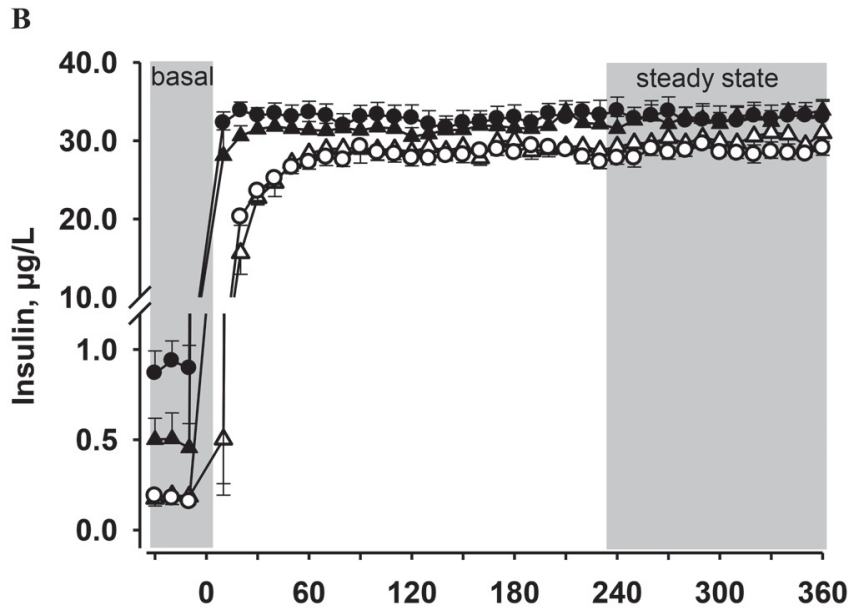

D

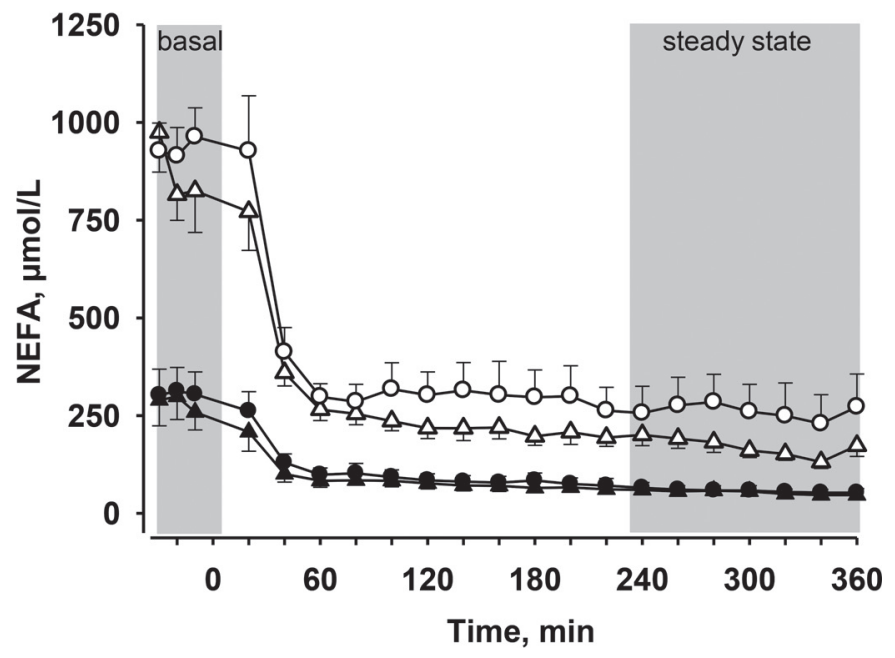

Figure 3. Plasma glucose, plasma insulin, glucose infusion rate (GIR), and plasma nonesterified fatty acids (NEFA) before (basal) and during a euglycemic-hyperinsulinemic clamp (EGHIC) with a steady state for the last $120 \mathrm{~min}$ in cows with low $[\mathrm{n}=9$; antepartum (ap) $\mathbf{\Lambda}$, postpartum (pp) $\Delta$ ] and high $(\mathrm{n}=10$; ap $\bullet$, pp $\bigcirc)$ liver fat concentrations. Values are LSM $\pm \mathrm{SE}$. 
Table 4. Plasma concentrations of glucose, insulin, and nonesterified fatty acids (NEFA); glucose infusion rate; metabolic clearance rate; insulin sensitivity index; and revised quantitative insulin sensitivity check index during antepartum and postpartum euglycemic-hyperinsulinemic clamp in cows with low and high liver fat concentrations (LLFC and HLFC, respectively)

\begin{tabular}{|c|c|c|c|c|c|c|c|c|}
\hline Variable $^{1,2}$ & \multicolumn{2}{|c|}{ Antepartum } & \multicolumn{2}{|c|}{ Postpartum } & $\mathrm{SE}$ & \multicolumn{3}{|c|}{ ANOVA ( $P$-value $)$} \\
\hline $\mathrm{bGC}, \mathrm{mmol} / \mathrm{L}$ & 4.12 & 4.18 & 3.60 & 3.65 & 0.18 & 0.8 & 0.01 & 1.0 \\
\hline $\mathrm{bIC}, \mu \mathrm{g} / \mathrm{L}$ & 0.49 & 0.90 & 0.19 & 0.19 & 0.10 & 0.08 & 0.001 & 0.03 \\
\hline $\mathrm{MCR}^{3}$ & 0.007 & 0.007 & 0.008 & 0.008 & 0.0003 & 0.5 & 0.01 & 0.7 \\
\hline $\mathrm{ISI}^{4}$ & 0.03 & 0.03 & 0.03 & 0.04 & 0.002 & 0.4 & 0.1 & 0.2 \\
\hline ssNEFA, $\mu \mathrm{mol} / \mathrm{L}$ & 53.7 & 57.1 & 170 & 269 & 34.8 & 0.2 & 0.001 & 0.2 \\
\hline
\end{tabular}

${ }^{1}$ Values are LSM with SE.

${ }^{2} \mathrm{bGC}=$ basal plasma glucose concentration; ssGIR = steady-state glucose infusion rate; bIC = basal plasma insulin concentration; $\mathrm{MCR}=$ metabolic clearance rate; ISI = insulin sensitivity index; RQUICKI = revised quantitative insulin sensitivity check index; bNEFA $=$ basal plasma NEFA concentration; sSNEFA = steady-state mean plasma NEFA concentration.

${ }^{3} \mathrm{MCR}=$ the ratio between the insulin infusion rate and the increase in steady-state insulin concentration (ssIC) above bIC.

${ }^{4} \mathrm{ISI}=$ the ratio of ssGIR $(\mu \mathrm{mol} / \mathrm{kg}$ of BW per min) to $\mathrm{ssIC}(\mu \mathrm{g} / \mathrm{L})$.

${ }^{5}$ Calculation of RQUICKI $=1 /[\log ($ glucose $)+\log ($ insulin $)+\log ($ NEFA $)]$ in basal plasma samples.

et al., 2013; Yadav et al., 2013), as confirmed by the present study. The lack of differences in plasma adiponectin concentrations and hepatic AMPK activation may support our present finding that insulin sensitivity in peripheral tissues was not affected by body condition or body fat mobilization around calving.

Stimulation of pancreatic insulin secretion by glucose did not indicate significant differences between HLFC and LLFC cows before and after calving, although the ssIC in HGC before calving was numerically greater, and relative insulin release after calving was greater, in HLFC than in LLFC cows. However, relative changes in insulin release pp were based on very low insulin concentrations, and the absolute increase in plasma insulin during HGC did not differ between groups. Therefore, the greater basal insulin concentration in ap HLFC cows seems not to result from elevated stimulation of insulin release by glucose. As for insulin secretion, data on the metabolic clearance rate of insulin during EGHIC before and after calving were comparable between HLFC and LLFC cows, indicating no association of body condition or body fat mobilization with insulin degradation.

Although variable body conditions and differences in NEFA release during the transition period did not affect pancreatic insulin secretion and responsiveness in peripheral tissues, mean respiratory quotient and fat and carbohydrate oxidation before and after calving differed between HLFC and LLFC cows (Börner et al., 2013). Obviously, differences in substrate utilization, as measured in respiration chambers (Börner et al., 2013), did not depend on insulin action. Because acetate, more

Table 5. Glucose turnover and glucose oxidation before and during a euglycemic-hyperinsulinemic clamp (EGHIC) in wk 3 postpartum in cows with low and high liver fat concentrations (LLFC and HLFC, respectively)

\begin{tabular}{|c|c|c|c|c|}
\hline \multirow[b]{2}{*}{ Variable $^{1,2}$} & \multicolumn{2}{|c|}{ Group } & \multirow[b]{2}{*}{$\mathrm{SE}$} & \multirow{2}{*}{$\begin{array}{c}\text { ANOVA } \\
(P \text {-value }) \\
\text { Group }\end{array}$} \\
\hline & LLFC & HLFC & & \\
\hline \multicolumn{5}{|c|}{ Glucose turnover, $\mathrm{mmol} /(\mathrm{kg}$ of $\mathrm{BW} \times \mathrm{h})$} \\
\hline beGP & 1.11 & 1.08 & 0.05 & 0.7 \\
\hline GlucRa $_{\text {EGHIC }}$ & 1.64 & 1.83 & 0.09 & 0.008 \\
\hline ceGP & 0.19 & 0.20 & 0.05 & 0.9 \\
\hline \multicolumn{5}{|c|}{ Glucose oxidation, $\mathrm{mmol} / \mathrm{kg}$ of $\mathrm{BW}$ per $\mathrm{h}$} \\
\hline Basal & 0.11 & 0.11 & 0.01 & 1.0 \\
\hline Clamp & 0.79 & 0.72 & 0.09 & 0.6 \\
\hline \multicolumn{5}{|c|}{ Glucose oxidation relative to glucose turnover, $\%$} \\
\hline Basal & 10.2 & 10.4 & 0.82 & 0.9 \\
\hline Clamp & 48.4 & 38.8 & 3.85 & 0.1 \\
\hline
\end{tabular}

${ }^{1}$ Values are LSM with SE.

${ }^{2}$ beGP $=$ basal endogenous glucose production; GlucRa $a_{\mathrm{EGHIC}}=$ glucose rate of appearance during EGHIC; ceGP $=$ clamp endogenous glucose production. 
than glucose, is a major substrate for energy utilization in ruminants and does not affect pancreatic insulin release, this might explain the minor association of insulin action with substrate utilization in HLFC and LLFC cows (Bergman, 1990; Brockman, 2005). However, infused insulin stimulates the glucose rate of appearance during EGHIC in HLFC more than in LLFC cows, a result consistent with the numerically greater ssGIR in HLFC cows during EGHIC after calving, although this increase was not significant when compared with ssGIR of LLFC cows. The greater glucose turnover in HLFC cows during insulin challenge may be the consequence of the greater mass of insulin-sensitive tissue; that is, body fat, in HLFC cows. When high amounts of glucose are available, glucose is used as substrate for fat synthesis in dairy cows (Al-Trad et al., 2009), and insulin stimulates lipogenesis in ruminants (Bell, 1995; Bauman, 2000; Vernon, 2005). However, these data clearly did not indicate impaired insulin responsiveness in over-conditioned dairy cows, compared with lean cows, around the time of calving, and they contrast with previous suggestions that elevated body condition and NEFA release may affect insulin-dependent glucose metabolism (McCann and Reimers, 1985; Pires et al., 2007). As stated above, we investigated maximal insulin responsiveness in the present study but not insulin sensitivity, as defined by De Koster and Opsomer (2013). The findings of McCann and Reimers (1985) showed a greater effect of body condition on insulin sensitivity than responsiveness. Therefore, different measurements of glucose-dependent insulin metabolism may explain these conflicting results, and a possible reduced insulin sensitivity may, at least in part, explain the elevated ap plasma insulin concentrations in HLFC cows.

The level of basal glucose oxidation was within the range of or slightly lower than in previously published results (Gohlke et al., 2013; Hötger et al., 2013). Interestingly, glucose oxidation related to glucose appearance rate during EGHIC pp was lower in HLFC than in LLFC cows. Although insulin stimulates glucose oxidation (Bauman, 2000), which increased during the EGHIC, the portion of oxidized glucose did not increase in the same manner because insulin-dependent glucose utilization might also result in elevated glycogen synthesis in muscle or fat synthesis in adipose tissue (Brockman and Laarveld, 1986; Al-Trad et al., 2009). Furthermore, the lower glucose oxidation is paralleled by the lower whole-body carbohydrate oxidation in HLFC compared with LLFC cows (Börner et al., 2013).

Changes in insulin-dependent glucose metabolism during the transition period were especially striking in terms of the differences in glucose-dependent insulin secretion during HGC before and after calving. The much greater ssGIR in HGC pp increased plasma glu- cose in the same manner as before calving, but glucose was not able to release insulin pp to the same extend as observed ap. The diminished glucose response to the release of pancreatic insulin during HGC after calving was first described by Sano et al. (1993), whose results supported early findings of impaired insulin release due to glucose or propionate challenges in lactating dairy cows (Lomax et al., 1979; Sartin et al., 1985). However, Sano et al. (1993) have reported lower ssGIR during HGC in lactating than nonlactating cows, which contradicts our results. The high ssGIR during HGC pp and the low insulin response at the same time pointed to glucose utilization in body tissue not being dependent on insulin action. In fact, glucose uptake in the mammary gland is insulin-independent (Laarveld et al., 1981; Bauman, 2000), and because milk production was much greater in this study than in the previous study (Sano et al., 1993), this difference may explain the variable ssGIR in HGC pp between the 2 studies.

The reduced insulin release pp after glucose treatment is probably related to lactation and the level of milk production because glucose-stimulated insulin secretion is lower in lactating than in nonlactating cows and lower in cows with greater milk production (Holtenius et al., 2003; Hammon et al., 2007, 2010). The reasons for the impaired glucose stimulation of pancreatic insulin release in lactating cows are presently not clear, but findings based on glucose tolerance tests suggest that the release of NEFA around calving or after feed deprivation may impair the secretion of pancreatic insulin after glucose challenge (Bossaert et al., 2008; Salin et al., 2012; Schoenberg et al., 2012). However, we observed no differences in ssIC in LLFC and HLFC cows, but plasma NEFA concentrations around calving differed between groups. Further studies showed that the reduced mass of pancreatic $\beta$ cells is involved in impaired insulin secretion in over-fed animals, and recent findings in calves have indicated changes in $\beta$-cell mass due to feeding intensity (Gupta et al., 2012; Prokop et al., 2015). However, feeding rumen-protected triglycerides or free fatty acids did not significantly modify the secretion of glucose-stimulated pancreatic insulin during HGC in dairy cows (Blum et al., 1999).

Changes in insulin responsiveness in peripheral tissues in EGHIC did not differ during the transition period in the present study, although insulin responsiveness decreases with the onset of lactation in ruminants (Vernon, 2005). The main reason for the present finding might be a compromised insulin responsiveness existing already during late pregnancy (Bell, 1995; Bauman, 2000). Furthermore, the nadir of plasma adiponectin concentration in the present study indicates that insulin responsiveness might have been impaired only close to the time of calving. However, the clamps in 
this study were performed in wk 5 ap and wk 3 pp, and differences in plasma adiponectin concentrations were less dominant at these time points. Therefore, stronger impairment of insulin responsiveness probably occurs immediately after calving. Our results on insulin responsiveness in peripheral tissues of lactating and nonlactating cows support the previous findings of Sano et al. (1993), who also did not detect differences in insulin responsiveness during EGHIC in lactating and nonlactating cows. Although insulin sensitivity and responsiveness are affected during the transition period, dairy cows may not develop a profound insulin-resistant state (Bauman and Griinari, 2001). In contrast, metabolic insulin clearance rate seems to be slightly enhanced after calving in the present study, and is also greater in lactating than nonlactating sheep (Faulkner and Pollock, 1990).

As expected, insulin decreased plasma NEFA concentration during the EGHIC clamp (Bauman and Griinari, 2001; Vernon, 2005; De Koster and Opsomer, 2013), but the relative decrease was not different before and after calving and reached approximately $20 \%$ of the basal NEFA concentration, which was slightly higher than previously reported (Kusenda et al., 2013). However, ssNEFA during EGHIC was greater after than before calving. Therefore, the plasma NEFA concentration during the EGHIC pp did not reach the level of concentration observed before calving. Insulin metabolism in adipose tissue depends on the physiological as well as the nutritional status of the animal, and lower insulin responsiveness in adipose tissue has been described for lactating versus nonlactating animals and during feed deprivation (Faulkner and Pollock, 1990; Vernon, 2005; Schoenberg et al., 2012). The decrease in plasma NEFA concentration was lower during the HGC than during the EGHIC studies, most probably because of a much lower plasma insulin concentration during the HGC than during the EGHIC pp. Therefore, reduced insulin secretion and lower insulin responsiveness in adipose tissue are important metabolic signals for an increased NEFA release at the beginning of lactation (Bauman, 2000; Vernon, 2005).

However, NEFA reduction by insulin action was comparable in HLFC and LLFC cows during HGC and EGHIC, both before and after calving, but cows differed in BCS and NEFA release around calving. Although, elevated fat mobilization and triglyceride concentrations in blood plasma induce insulin resistance in adipose tissue (Pires et al., 2007; Zachut et al., 2013), recent studies have indicated that the depression of NEFA release by insulin does not depend on body condition before calving (De Koster et al., 2015). Differences in fat mobilization between HLFC and LLFC cows during the transition period could not obviously be explained by differences in peripheral insulin responsiveness. Other metabolic and endocrine factors may play a significant role in the stimulation of body fat mobilization around calving, especially in over-conditioned dairy cows.

\section{CONCLUSIONS}

This study showed a minor influence of different metabolic types (i.e., cows with high versus low LFC and degrees of fat mobilization around calving) on insulindependent glucose utilization and glucose-dependent pancreatic insulin release. Changes in insulin-dependent glucose utilization during the transition period were also minor, but there was a distinct decrease in glucosedependent pancreatic insulin release during early lactation. Reduced stimulation of insulin secretion seems to be one of the key homeorhetic mechanisms directing the supply of nutrients to the mammary gland, but reduced pancreatic insulin release does not explain differences in body fat mobilization and NEFA release around calving in LLFC and HLFC cows.

\section{ACKNOWLEDGMENTS}

We thank Kirsten Karpati, Ute Lüdtke, Axel Fischer, the staff at the Experimental Cattle Facility of the FBN (Bernd Stabenow and co-workers), and the animal caretakers (Dirk Oswald, Roland Gaeth, Astrid Schulz, Kerstin Pilz, and Kerstin Korinth) at the Institute of Nutritional Physiology (Dummerstorf, Germany) for their help with the biochemical analyses and animal care. We further acknowledge the help of the Cattle Breeding Organization of Mecklenburg-West Pomerania (Rinderallianz, Woldegk, Germany) and the Griepentrog Farm (Steinhagen, Germany) for providing the assortment of cows. The Deutsche Forschungsgemeinschaft (DFG; Bonn, Germany; HA 4372/7-1) supported this study.

\section{REFERENCES}

Al-Trad, B., K. Reisberg, T. Wittek, G. B. Penner, A. Alkaassem, G. Gäbel, M. Fürll, and J. R. Aschenbach. 2009. Increasing intravenous infusions of glucose improve body condition but not lactation performance in mid-lactation dairy cows. J. Dairy Sci. 92:5645-5658.

Andersen, J. B., D. G. Mashek, T. Larsen, M. O. Nielsen, and K. L. Ingvartsen. 2002. Effects of hyperinsulinaemia under euglycaemic condition on liver fat metabolism in dairy cows in early and midlactation. J. Vet. Med. A Physiol. Pathol. Clin. Med. 49:65-71.

Aschenbach, J. R., N. B. Kristensen, S. S. Donkin, H. M. Hammon, and G. B. Penner. 2010. Gluconeogenesis in dairy cows: The secret of making sweet milk from sour dough. IUBMB Life 62:869-877.

Bauman, D. E. 2000. Regulation of nutrient partitioning during lactation: Homeostasis and homeorhesis revisited. Pages 311-328 in Ruminant Physiology: Digestion, Metabolism, Growth and Reproduction. P. B. Cronje, ed. CAB International, Wallingford, UK. 
Bauman, D. E., and J. M. Griinari. 2001. Regulation and nutritional manipulation of milk fat: Low-fat milk syndrome. Livest. Prod. Sci. 70:15-29.

Bell, A. W. 1995. Regulation of organic nutrient metabolism during transition from late pregnancy to early lactation. J. Anim. Sci. 73:2804-2819.

Bergman, E. N. 1990. Energy contributions of volatile fatty acids from the gastrointestinal tract in various species. Physiol. Rev. 70:567-590.

Bergman, E. N., S. S. Reulein, and R. E. Corlett. 1989. Effects of obesity on insulin sensitivity and responsiveness in sheep. Am. J. Physiol. 257:E772-E781.

Blum, J. W., R. M. Bruckmaier, and P. Y. Vacher. 1999. Insulindependent whole-body glucose utilization and insulin-responses to glucose in week 9 and week 19 of lactation in dairy cows fed rumen-protected crystalline fat or free fatty acids. Domest. Anim. Endocrinol. 16:123-134.

Boden, G., P. Cheung, T. P. Stein, K. Kresge, and M. Mozzoli. 2002 FFA cause hepatic insulin resistance by inhibiting insulin suppression of glycogenolysis. Am. J. Physiol. Endocrinol. Metab. 283:E12-E19.

Börner, S., E. Albrecht, C. Schäff, S. Hacke, U. Kautzsch, M. Derno, H. M. Hammon, M. Rontgen, H. Sauerwein, and B. Kuhla. 2013 Reduced AgRP activation in the hypothalamus of cows with high extent of fat mobilization after parturition. Gen. Comp. Endocrinol. 193:167-177.

Bossaert, P., J. L. M. R. Leroy, S. De Vliegher, and G. Opsomer. 2008 Interrelations between glucose-induced insulin response, metabolic indicators, and time of first ovulation in high-yielding dairy cows. J. Dairy Sci. 91:3363-3371.

Brockman, R. P. 2005. Glucose and short-chain fatty acid metabolism. Pages 291-310 in Quantitative aspects of ruminant digestion and metabolism J. Dijkstra, J. M. Forbes, and J. France, ed. CABI Publishing, Wallingford, UK.

Brockman, R. P., and B. Laarveld. 1986. Hormonal-regulation of metabolism in ruminants-A review. Livest. Prod. Sci. 14:313-334.

Combs, T. P., and E. B. Marliss. 2014. Adiponectin signaling in the liver. Rev. Endocr. Metab. Disord. 15:137-147.

De Koster, J., M. Hostens, M. Van Eetvelde, K. Hermans, S. Moerman, H. Bogaert, E. Depreester, W. Van den Broeck, and G. Opsomer. 2015. Insulin response of the glucose and fatty acid metabolism in dry dairy cows across a range of body condition scores. J. Dairy Sci. 98:4580-4592.

De Koster, J. D., and G. Opsomer. 2013. Insulin resistance in dairy cows. Vet. Clin. North Am. Food Anim. Pract. 29:299-322.

DeFronzo, R. A., J. D. Tobin, and R. Andres. 1979. Glucose clamp technique: A method for quantifying insulin secretion and resistance. Am. J. Physiol. 237:E214-E223.

Drackley, J. K., T. R. Overton, and G. N. Douglas. 2001. Adaptations of glucose and long-chain fatty acid metabolism in liver of dairy cows during the periparturient period. J. Dairy Sci. 84(E Suppl.):100-112.

Duske, K., H. M. Hammon, A. K. Langhof, O. Bellmann, B. Losand, K. Nürnberg, G. Nürnberg, H. Sauerwein, H. M. Seyfert, and C. C. Metges. 2009. Metabolism and lactation performance in dairy cows fed a diet containing rumen-protected fat during the last twelve weeks of gestation. J. Dairy Sci. 92:1670-1684.

Edmonson, A. J., I. J. Lean, L. D. Weaver, T. Farver, and G. Webster. 1989. A body condition scoring chart for Holstein dairy cows. J. Dairy Sci. 72:68-78.

Faulkner, A., and H. T. Pollock. 1990. Metabolic responses to euglycaemic hyperinsulinaemia in lactating and non-lactating sheep in vivo. J. Endocrinol. 124:59-66.

GfE (German Society of Nutrition Physiology). 2001. Empfehlungen zur Energie- und Nährstoffversorgung der Milchkühe und Aufzuchtrinder [Recommended energy and nutrient supply for dairy cows and heifers]. Ausschuss für Bedarfsnormen der Gesellschaft für Ernährungsphysiologie No. 8. DLG Verlag, Frankfurt am Main, Germany.

GfE (German Society of Nutrition Physiology). 2008. New equations for predicting metabolisable energy of grass and maize products for ruminants. Mitteilung des Ausschusses für Bedarfsnormen der Gesellschaft für Ernährungsphysiologie. Proc. Soc. Nutr. Physiol. $17: 191-198$.

Gohlke, A., C. J. Ingelmann, G. Nürnberg, J. M. Weitzel, H. M. Hammon, S. Görs, A. Starke, S. Wolffram, and C. C. Metges. 2013 Influence of 4-week intraduodenal supplementation of quercetin on performance, glucose metabolism, and mRNA abundance of genes related to glucose metabolism and antioxidative status in dairy cows. J. Dairy Sci. 96:6986-7000.

Grummer, R. R. 1993. Etiology of lipid-related metabolic disorders in periparturient dairy cows. J. Dairy Sci. 76:3882-3896.

Gupta, D., C. B. Krueger, and G. Lastra. 2012. Over-nutrition, obesity and insulin resistance in the development of beta-cell dysfunction. Curr. Diabetes Rev. 8:76-83.

Hammon, H. M., O. Bellmann, J. Voigt, F. Schneider, and C. Kühn. 2007. Glucose-dependent insulin response and milk production in heifers within a segregating resource family population. J. Dairy Sci. 90:3247-3254.

Hammon, H. M., C. C. Metges, P. Junghans, F. Becker, O. Bellmann, F. Schneider, G. Nürnberg, P. Dubreuil, and H. Lapierre. 2008 Metabolic changes and net portal flux in dairy cows fed a ration containing rumen-protected fat as compared to a control diet. J. Dairy Sci. 91:208-217.

Hammon, H. M., C. C. Metges, A. Schulz, P. Junghans, J. Steinhoff, F. Schneider, R. Pfuhl, R. M. Bruckmaier, R. Weikard, and C. Kühn. 2010. Differences in milk production, glucose metabolism, and carcass composition of 2 Charolais $\mathrm{x}$ Holstein F-2 families derived from reciprocal paternal and maternal grandsire crosses. J. Dairy Sci. 93:3007-3018.

Hammon, H. M., G. Stürmer, F. Schneider, A. Tuchscherer, H. Blum, T. Engelhard, A. Genzel, R. Staufenbiel, and W. Kanitz. 2009 Performance and metabolic and endocrine changes with emphasis on glucose metabolism in high-yielding dairy cows with high and low fat content in liver after calving. J. Dairy Sci. 92:1554-1566.

Hayirli, A. 2006. The role of exogenous insulin in the complex of hepatic lipidosis and ketosis associated with insulin resistance phenomenon in postpartum dairy cattle. Vet. Res. Commun. 30:749-774.

Holtenius, K., S. Agenas, C. Delavaud, and Y. Chilliard. 2003. Effects of feeding intensity during the dry period. 2. Metabolic and hormonal responses. J. Dairy Sci. 86:883-891.

Holtenius, P., and K. Holtenius. 2007. A model to estimate insulin sensitivity in dairy cows. Acta Vet. Scand. 49:29.

Hötger, K., H. M. Hammon, C. Weber, S. Görs, A. Tröscher, R. M. Bruckmaier, and C. C. Metges. 2013. Supplementation of conjugated linoleic acid in dairy cows reduces endogenous glucose production during early lactation. J. Dairy Sci. 96:2258-2270.

Hugi, D., L. Tappy, H. Sauerwein, R. M. Bruckmaier, and J. W. Blum. 1998. Insulin-dependent glucose utilization in intensively milk-fed veal calves is modulated by supplemental lactose in an age-dependent manner. J. Nutr. 128:1023-1030.

Ingvartsen, K. L., and J. B. Andersen. 2000. Integration of metabolism and intake regulation: A review focusing on periparturient animals. J. Dairy Sci. 83:1573-1597.

Junghans, P., S. Görs, I. S. Lang, J. Steinhoff, H. M. Hammon, and C. C. Metges. 2010. A simplified mass isotopomer approach to estimate gluconeogenesis rate in vivo using deuterium oxide. Rapid Commun. Mass Spectrom. 24:1287-1295.

Junghans, P., J. Voigt, W. Jentsch, C. C. Metges, and M. Derno. 2007. The ${ }^{13} \mathrm{C}$ bicarbonate dilution technique to determine energy expenditure in young bulls validated by indirect calorimetry. Livest. Sci. 110:280-287.

Kessel, S., M. Stroehl, H. H. Meyer, S. Hiss, H. Sauerwein, F. J. Schwarz, and R. M. Bruckmaier. 2008. Individual variability in physiological adaptation to metabolic stress during early lactation in dairy cows kept under equal conditions. J. Anim. Sci. 86:29032912

Kien, C. L. 1989. Isotopic dilution of $\mathrm{CO}_{2}$ as an estimate of $\mathrm{CO}_{2}$ production during substrate oxidation studies. Am. J. Physiol. 257:E296-E298.

Kusenda, M., M. Kaske, M. Piechotta, L. Locher, A. Starke, K. Huber, and J. Rehage. 2013. Effects of dexamethasone-21-isonicotinate on 
peripheral insulin action in dairy cows 5 days after surgical correction of abomasal displacement. J. Vet. Intern. Med. 27:200-206.

Laarveld, B., D. A. Christensen, and R. P. Brockman. 1981. The effect of insulin on net metabolism of glucose and amino acids by the bovine mammary gland. Endocrinology 108:2217-2221.

Lomax, M. A., G. D. Baird, C. B. Mallinson, and H. W. Symonds. 1979. Differences between lactating and non-lactating dairycows in concentration and secretion rate of insulin. Biochem. J. 180:281-289.

McCann, J. P., and T. J. Reimers. 1985. Glucose response to exogenous insulin and kinetics of insulin metabolism in obese and lean heifers. J. Anim. Sci. 61:612-618.

Mielenz, M., B. Mielenz, S. P. Singh, C. Kopp, J. Heinz, S. Häussler, and H. Sauerwein. 2013. Development, validation, and pilot application of a semiquantitative Western blot analysis and an ELISA for bovine adiponectin. Domest. Anim. Endocrinol. 44:121-130.

Mitrakou, A., H. Vuorinenmarkkola, G. Raptis, I. Toft, M. Mokan, P. Strumph, W. Pimenta, T. Veneman, T. Jenssen, G. Bolli, M. Korytkowski, H. Ykijarvinen, and J. Gerich. 1992. Simultaneous assessment of insulin-secretion and insulin sensitivity using a hyperglycemic clamp. J. Clin. Endocrinol. Metab. 75:379-382.

Naumann, C., and R. Bassler. 2004. Die chemische Untersuchung von Futtermittel. VDLUFA-Verlag, Darmstadt, Germany.

Ohgi, T., S. Kamimura, Y. Minezaki, and M. Takahashi. 2005. Relationship between fat accumulation in the liver and energy intake, milk fat yield and blood metabolites in dairy cows. Anim. Sci. J. 76:549-557.

Pires, J. A. A., A. H. Souza, and R. R. Grummer. 2007. Induction of hyperlipidemia by intravenous infusion of tallow emulsion causes insulin resistance in Holstein cows. J. Dairy Sci. 90:2735-2744.

Prokop, L., M. Kaske, P. Maccari, R. Lucius, H. J. Kunz, and S. Wiedemann. 2015. Intensive rearing of male calves during the first three weeks of life has long-term effects on number of islets of Langerhans and insulin stained area in the pancreas. J. Anim. Sci. 93:988-998.

Reist, M., D. Erdin, D. von Euw, K. Tschuemperlin, H. Leuenberger, C. Delavaud, Y. Chilliard, H. M. Hammon, N. Kuenzi, and J. W. Blum. 2003. Concentrate feeding strategy in lactating dairy cows: Metabolic and endocrine changes with emphasis on leptin. J. Dairy Sci. 86:1690-1706.

Salin, S., J. Taponen, K. Elo, I. Simpura, A. Vanhatalo, R. Boston, and T. Kokkonen. 2012. Effects of abomasal infusion of tallow or camelina oil on responses to glucose and insulin in dairy cows during late pregnancy. J. Dairy Sci. 95:3812-3825.

Sano, H., S. Narahara, T. Kondo, A. Takahashi, and Y. Terashima. 1993. Insulin responsiveness to glucose and tissue responsiveness to insulin during lactation in dairy-cows. Domest. Anim. Endocrinol. 10:191-197.

Sartin, J. L., K. A. Cummins, R. J. Kemppainen, D. N. Marple, C. H. Rahe, and J. C. Williams. 1985. Glucagon, insulin, and growth hormone responses to glucose infusion in lactating dairy cows. Am. J. Physiol. 248:E108-E114.

SAS Institute. 2013. SAS/STAT ${ }^{\circledR} 9.4$ User's Guide. SAS Institute Inc., Cary, NC.

Schäff, C., S. Börner, S. Hacke, U. Kautzsch, D. Albrecht, H. M. Hammon, M. Röntgen, and B. Kuhla. 2012. Increased anaplerosis, TCA cycling, and oxidative phosphorylation in the liver of dairy cows with intensive body fat mobilization during early lactation. J. Proteome Res. 11:5503-5514.

Scheuer, B. H., Y. Zbinden, P. Schneiter, L. Tappy, J. W. Blum, and H. M. Hammon. 2006. Effects of colostrum feeding and glucocorticoid administration on insulin-dependent glucose metabolism in neonatal calves. Domest. Anim. Endocrinol. 31:227-245.

Schoenberg, K. M., R. M. Ehrhardt, and T. R. Overton. 2012. Effects of plane of nutrition and feed deprivation on insulin responses in dairy cattle during late gestation. J. Dairy Sci. 95:670-682.

Schröder, U. J., and R. Staufenbiel. 2006. Invited review: Methods to determine body fat reserves in the dairy cow with special regard to ultrasonographic measurement of back fat thickness. J. Dairy Sci. 89:1-14.

Tamminga, S., P. A. Luteijn, and R. G. M. Meijer. 1997. Changes in composition and energy content of liveweight loss in dairy cows with time after parturition. Livest. Prod. Sci. 52:31-38.

Thaller, G., C. Kühn, A. Winter, G. Ewald, O. Bellmann, J. Wegner, H. Zuhlke, and R. Fries. 2003. DGAT1, a new positional and functional candidate gene for intramuscular fat deposition in cattle. Anim. Genet. 34:354-357.

Vernon, R. G. 2005. Metabolic regulation. Pages 443-468 in Quantitative aspects of ruminant digestion and metabolism. J. Dijkstra, J M. Forbes, and J. France, ed. CABI Publishing, Wallingford, UK.

Weber, C., C. Hametner, A. Tuchscherer, B. Losand, E. Kanitz, W. Otten, S. P. Singh, R. M. Bruckmaier, F. Becker, W. Kanitz, and H. M. Hammon. 2013. Variation in fat mobilization during early lactation differently affects feed intake, body condition, and lipid and glucose metabolism in high-yielding dairy cows. J. Dairy Sci. 96:165-180.

Yadav, A., M. A. Kataria, V. Saini, and A. Yadav. 2013. Role of leptin and adiponectin in insulin resistance. Clin. Chim. Acta 417:80-84.

Zachut, M., H. Honig, S. Striem, Y. Zick, S. Boura-Halfon, and U. Moallem. 2013. Periparturient dairy cows do not exhibit hepatic insulin resistance, yet adipose-specific insulin resistance occurs in cows prone to high weight loss. J. Dairy Sci. 96:5656-5669. 